\title{
DETERMINANTS OF COMPETIIIVE INTENSITY: SUBSTITUTABILITY AND PRICING POLICY
}

\author{
Paul COCIOC ${ }^{\text {a* }}$ \\ a) Babeș-Bolyai University, Faculty of Economics and Business Administration, \\ Cluj-Napoca, Romania
}

Please cite this article as:

Article History:

Cocioc, P., 2021. Determinants of competitive intensity: substitutability and pricing policy. Review of Economic Studies and Research Virgil Madgearu, 14(1), pp.5-16.

doi: 10.24193/RVM.2021.14.70.

Abstract: The article offer a critical perspective of several elements and some
associated indicators used in characterizing and estimating the intensity of
competition (i.e., the extent to which the mutual pressure of rivals is exerted on the
market). We focus on the pricing policies of the firms and its impact and expected
responses from competitors. Influences of substitutes and overall production
capacity surplus are also analyzed. Key words: competition; competitive intensity; imperfect competition; price signals

JEL Classification: D4O; D43; L11; L13; L41

(C) 2021 Alma Mater Publishing House. All rights reserved.

* Corresponding author. E-mail address: paul.cocioc@econ.ubbcluj.ro. 


\section{References:}

1. Akerlof, G.A., 1970. The Market for 'Lemons': Quality Uncertainty and the Market Mechanism. Quarterly Journal of Economics. 84(3), pp.488-500. https://doi:10.2307/1879431.

1. Baumol, W.J., 1982. Contestable markets: an uprising in the theory of industry structure. American Economic Review. 72(1), pp.1-15.

2. Cocioc, P., 2014. Measuring Competition in Romania - Basic Principles and Extensions. Review of Economic Studies and Research Virgil Madgearu, 7(1), pp.41-68.

3. Cocioc, P., 2000. Foundations of a revisited concept of perfect competition. Studia Universitatis Babes-Bolyai, Oeconomica, 45(1), pp.107-110.

4. Cocioc, P., 1999. Teoria concurenței în retrospectivă. Cluj-Napoca: Presa Universitară Clujeană.

5. Forchheimer, K., and Kuhn, W., 1983. Imperfect Monopoly: Some Theoretical Considerations. Nebraska Journal of Economics and Business, 22(2), pp. 65-77. Available at: <http://www.jstor.org/ stable/40472748> [Accessed 13 November 2020].

6. European Commision, 2003. Glossary of terms used in EU competition policy: antitrust and control of concentrations. Luxembourg: Office for Official Publications of the European Communities. Available at: <https://op.europa.eu/en/publicationdetail/-/publication/10oe1bc8-cee3-4f65-9b3o-e232ec3064d6> [Accessed 13 November 2020].

7. Hotelling, H., 1929. Stability in Competition. The Economic Journal, 39(153), pp.41-57.

8. Karier, T., 1993. Beyond Competition. The Economics of Mergers and Monopoly Power. New York: Sharpe.

9. Kotowitz, Y., 2008. Moral Hazard. In: Palgrave Macmillan (eds.) The New Palgrave Dictionary of Economics. London: Palgrave Macmillan. https://doi.org/10.1057/978-1-349-95121-5_1219-2.

10. Laffont, J.J., 2008. Externalities. In: Palgrave Macmillan (eds) The New Palgrave Dictionary of Economics. London: Palgrave Macmillan. https://doi.org/10.1057/978-1-349-95121-5_126-2.

11. Ledyard, J.O., 2008. Market Failure. In: Palgrave Macmillan (eds) The New Palgrave Dictionary of Economics. London: Palgrave Macmillan. https://doi.org/10.1057/978-1-349-95121-5_1052-2 
12. Mehta, P.S. and Evenet, E.J., 2006. Promoting Competition Around the World: A Diversity of Rationales and Approaches. In: Mehta, P.S. (ed). Competition Regimes in the World: A Civil Society Report. Jaipur: CUTS International, pp.i-xi. Available at: <https:// competitionregimes.com/pdf/IntroductoryChapter.pdf> [Accessed 13 November 2020].

13. Porter, M.E., 1980. Competitive Strategy: Techniques for Analyzing Industries and Competitors. New York: Free Press.

14. Porter, M.E., 1985. Competitive Advantage. Creating and Sustaining Superior Performance. New York: Free Press.

15. Rainelli, M., 2003. La nouvelle theorie du commerce international. Paris: La Decouverte.

16. Robinson, J.V., 1980. What is Perfect Competition? Collected Economic Papers. Cambridge, Mass.: M.I.T. Press, vol.1, pp.20-35.

17. Stigler, G., 1957. Perfect Competition, Historically Contemplated. Journal of Political Economy, 65(1), pp.1-17. https://doi. org/10.1086/257878.

18. ***, 2016. Council of economic advisers issue brief [online] Benefits of competition and indicators of market power. Available at: <https://obamawhitehouse.archives.gov/sites/default/files/page/ files/20160414_cea_competition_issue_brief.pdf> [Accessed 13 November 2020]. 